\title{
A Novel Method to Isolate Odontoblasts from Rat Incisor
}

\author{
L. Guo, ${ }^{1}$ J. E. Berry, ${ }^{3}$ M. J. Somerman, ${ }^{3,4}$ R. M. Davidson ${ }^{1,2}$ \\ ${ }^{1}$ Division of Basic Sciences, New York University College of Dentistry, 345 East 24th Street, New York, New York 10010, USA \\ ${ }^{2}$ Department of Periodontics, New York University College of Dentistry, New York, New York, 10010, USA \\ ${ }^{3}$ Department of Periodontics/Prevention/Geriatrics, University of Michigan, Ann Arbor, Michigan, USA \\ ${ }^{4}$ Department of Pharmacology, University of Michigan, Ann Arbor, Michigan, USA
}

Received: 21 July 1998 / Accepted: 24 September 1999

\begin{abstract}
Historically, odontoblasts have been isolated from rat incisor using a surgical curette to separate these cells from the dentin. Isolation of odontoblasts using this approach typically resulted in cells with membrane properties that made the application of patch-clamp electrophysiological techniques prohibitive. The studies here describe a new procedure for isolating mature odontoblasts from adult rat incisor to obtain enriched populations of intact, viable odontoblasts that can be readily studied using patch-clamp methodologies. Identification of isolated cells as odontoblasts was confirmed using in situ mRNA hybridization for expression of dentin sialoprotein, osteocalcin, bone sialoprotein, and type I collagen, and calcium flux was monitored in these cells by means of fura- 2 microfluorometry. We suggest that either single odontoblasts or clusters of these cells isolated by this new method would be an ideal preparation for the study of odontoblast properties using electrophysiological techniques, in situ hybridization and/or microfluorometry.
\end{abstract}

Key words: Odontoblast — Dentin sialoprotein — Bone sialoprotein - Osteocalcin - Fura-2.

Odontoblasts are perhaps the most striking cells of the dental pulp, forming a morphologically distinct and welldefined monolayer lining its periphery. Functionally, odontoblasts play a key role in the formation, maintenance, and repair of dentin; in response to the appropriate cue, these cells produce an extracellular matrix that subsequently mineralizes to form either primary or secondary dentin [1]. In addition to its critical role in dentinogenesis, it has long been postulated that the odontoblast may also be involved in sensory transduction in teeth [2].

Though mechanisms remain unclear, recent studies strongly suggest that odontoblast ion channels may have a functional role in dentin metabolism [3-6], in the response to injury to teeth [7-9], as well as in the transduction of sensory stimulation of dental pulp [10]. Thus, to confirm the existence of such channels in the odontoblast membrane and to study their functional properties, patch-clamp recording techniques were applied to these cells [11]. The first step in patch-clamp recording is to form a high-resistance electrical seal, i.e., a gigaOhm seal, between the patch pipette and a cell's membrane [12], and in initial studies, odontoblasts

Correspondence to: R. M. Davidson were isolated using a standard preparation [13]. However, an adequate seal was virtually impossible to achieve using this preparation, perhaps due to the granular surface of the cell's membrane (Fig. 1a). Indeed, during isolation of odontoblasts using this procedure, the dentinal process is typically sheared off, possibly resulting in physical damage to the overall membrane. Accordingly, an alternative protocol was developed to isolate odontoblasts from rat incisor. This new method resulted in dissociated cells with a smooth, nongranular surface and surprisingly intact processes (Fig. 1b), and most importantly, the ability to obtain the requisite high-resistance seal on a routine basis. Positive identification of these cells as odontoblasts was confirmed using in situ mRNA hybridization, and a characteristic fluorescent image could be obtained by incubating these cells with fura-2 acetoxymethyl ester (fura-2 AM), a calcium-binding fluorochrome.

\section{Materials and Methods}

All animal care and use protocols were approved by the New York University Animal Welfare Committee. Adult Sprague-Dawley rats of either sex weighing 200-400 g were used in these studies. Animals were killed by placing them in an air-tight chamber filled with $\mathrm{CO}_{2}$. Gingiva and periodontal connective tissues were dissected along the tooth surface, the tooth was elevated using a No. 22 scalpel blade (Becton-Dickinson, Rutherford, NJ), and the incisor was removed from its alveolus using a curved hemostat. Typically, all four incisors were extracted within 5-10 minutes following sacrifice of the animal, and the extracted incisors were immediately submerged in cold $\left(3-5^{\circ} \mathrm{C}\right)$ extracellular saline (ECS), consisting of (in mM) $140 \mathrm{NaCl}, 3 \mathrm{KCl}, 1 \mathrm{CaCl}_{2}, 1 \mathrm{MgCl}_{2}$ 10 HEPES, adjusted to $\mathrm{pH} 7.3-7.4$ with $\mathrm{NaOH}$. After all connective tissues, bone, and blood adhering to the outside of the tooth were carefully removed with a small piece of sterile gauze, the coronal half of the tooth was clamped to the specimen chuck of an ISOMET Low Speed Saw (Buehler, Lake Bluff, IL), and sectioned transversely through the pulp at a speed of 100 RPM. During sectioning, the tooth/blade interface was continually bathed in cold ECS. Slices were individually collected with a fine forceps immediately after sectioning, and placed in a $35 \mathrm{~mm}$ culture dish (Falcon, Franklin Lakes, NJ) filled with cold ECS. Approximately 10-15 slices, each $\sim 500 \mu \mathrm{m}$ thick, were obtained from each incisor. Prior to enzyme treatment, slices were rinsed three times with cold ECS.

For each preparation, dentin slices containing pulp tissue from two to four incisors were suspended in $2 \mathrm{ml}$ of a standard enzyme solution (see below) in a $15 \mathrm{ml}$ polypropylene tube (Falcon) and incubated for $10-20$ minutes in a water bath at $35-37^{\circ} \mathrm{C}$. Following incubation, the suspension containing the dentin slices was passed through a series of four Pasteur pipettes of successively 
smaller tip diameters, ranging from approximately 2.0 to $0.5 \mathrm{~mm}$. This effectively separated the dentin from the odontoblast cells, and also disaggregated odontoblast cells from pulpal connective tissues. The suspension was then transferred to a fresh polypropylene tube and ECS was added to a volume of $15 \mathrm{ml}$. After gentle agitation, the suspension was centrifuged at $200 \mathrm{~g}$ for 3 minutes. After centrifugation, the supernatant was discarded and the pellet was resuspended in $2 \mathrm{ml} \mathrm{ECS}$ and stored at $3-5^{\circ} \mathrm{C}$ until required. The entire isolation procedure was typically completed within 40 minutes after sacrifice of the animal.

The standard enzyme solution consisted of collagenase IA (3 $\mathrm{mg} / \mathrm{ml})$ and protease $\mathrm{I}(0.25 \mathrm{mg} / \mathrm{ml})$ in $\mathrm{Ca}^{2+}$ and $\mathrm{Mg}^{2+}$-free ECS, filtered, and stored in $2 \mathrm{ml}$ aliquots at $-20^{\circ} \mathrm{C}$ for up to 2 weeks. In several experiments, the following modifications were carried out in an attempt to improve both isolation and maintenance of odontoblasts: (1) ECS was replaced by Dulbecco's modified Eagle medium (DMEM) (Life Technologies, Grand Island, NY) with addition of heat-inactivated fetal bovine serum (15\%), penicillin $(220 \mu \mathrm{g} / \mathrm{ml})$, and streptomycin $(200 \mu \mathrm{g} / \mathrm{ml})$; (2) the standard enzyme solution was replaced by a mixture of i) $2 \mathrm{mg} / \mathrm{ml}$ collagenase IA, $1 \mathrm{mg} / \mathrm{ml}$ trypsin 1 and $0.5 \mathrm{mg} / \mathrm{ml}$ elastase (Worthington Biochemical Co., Freehold, NJ), ii) $3 \mathrm{mg} / \mathrm{ml}$ collagenase IA and 0.25 $\mathrm{mg} / \mathrm{ml}$ elastase, iii) $1 \mathrm{mg} / \mathrm{ml}$ protease I, or iv) $2 \mu \mathrm{g} / \mathrm{ml}$ DNAase I, $100 \mu \mathrm{g} / \mathrm{ml}$ hyaluronidase IS or $1 \mathrm{mM}$ sodium-pyruvic acid were added to the standard enzyme solution; (3) slices were perfused with $\mathrm{O}_{2}$ during the incubation or (4) the final suspension was stored in $\mathrm{CO}_{2}$ incubator at $37^{\circ} \mathrm{C}$ with $5 \mu \mathrm{g} / \mathrm{ml}$ insulin, $50 \mu \mathrm{g} / \mathrm{ml}$ ascorbic acid, $10 \mathrm{nM}$ dexamethasone, $10 \mathrm{mM} \beta$-glycerolphosphate, and $1 \mathrm{mM}$ pyruvic acid in DMEM medium. To promote attachment of odontoblasts, surfaces were coated with (1) Cell-Tak (Collaborative Biomedical, Bedford, MA), (2) Sigmacote, 0.1\%, (3) Fibronectin, (4) Collagen I, or poly-L-lysine. Unless otherwise noted, all reagents, chemicals, and enzymes were purchased from Sigma Chemical Corp (St. Louis, MO). Odontoblasts were identified on the basis of their characteristic morphology. Criteria for selection included $(i)$ a columnar or cuboidal cell body ranging from 15 to $25 \mu \mathrm{m}$, (ii) a 1 - to $2-\mu \mathrm{m}$-thick process extending from the distal aspect of the cell body at least 2 to 3 times the length of the cell, and (iii) a single, polarized nucleus. For patch-clamp recording (Fig. 2a), cells were stored at $3-5^{\circ} \mathrm{C}$ in ECS, transferred to a $35 \mathrm{~mm}$ culture dish precoated with $0.01 \%$ poly-L-lysine, and allowed to settle for 2-4 minutes prior to recording. Both bath and pipette solutions contained an intracellular-like solution (ICS), consisting of $5 \mathrm{NaCl}, 140 \mathrm{KCl}, 1 \mathrm{CaCl}_{2}, 1 \mathrm{MgCl}_{2}$, and $10 \mathrm{HEPES}$, adjusted to $\mathrm{pH} 7.3-7.4$ with $\mathrm{KOH}$. For microfluorometry, a $20 \mu \mathrm{L}$ cell suspension of odontoblasts was plated on a glass coverslip precoated with $0.01 \%$ poly-L-lysine. Cells were allowed to settle for 3 minutes at room temperature, then incubated with $2 \mu \mathrm{M}$ fura-2 AM (Molecular Probes, Eugene, OR) in ECS at $37^{\circ} \mathrm{C}$ for 30 minutes. After loading, cells were rinsed three times with ECS and then placed in a perfusion chamber mounted on the stage of an inverted microscope (IMT-2, Olympus, Inc., Tokyo, Japan) and viewed using a $40 \times$ objective. Cells were illuminated at wavelengths of 340 and $380 \mathrm{~nm}$ using a $70 \mathrm{~W}$ xenon bulb as a light source, and the emitted light was fed into a photomultiplier via an ultraviolet dichroic mirror and $510 \mathrm{~nm}$ interference filter (IonOptix Corp, Milton, MA). Measurements of fluorescent intensity of positively identified odontoblasts were obtained at a rate of 33/second, and the 340/380 ratio was computed using dedicated software (IonOptix Corp) to calculate the calcium concentration, as described by Grynkiewicz et al. [14].

Standard in situ hybridization procedures were used [15], with slight modifications. Specific probes included (1) dentin sialoprotein (DSP): the $1.2 \mathrm{~kb}$ rat full-length DSP cDNA cloned into pGEM-7z(+) vector [16, 17] (a gift from Dr. H. Ritchie and Dr. W. T. Butler, University of Texas, Houston); (2) bone sialoprotein (BSP): PM-BSP consists of $1-\mathrm{kb}$ of mouse cDNA in PCR II [18] (a gift from Dr. M. Young, NIH/NIDCR); (3) osteocalcin (OCN): $400 \mathrm{bp}$ of mouse OCN cDNA cloned into pSP65 cloning vector [19]; (4) collagen type I: $1 \mathrm{~kb}$ of bovine type I collagen cloned into Bluescript [20] (a gift from Dr. M. Young, NIH/NIDCR). Appropriate promoters in these vectors were utilized to generate antisense (AS) and sense (S) probes using the Riboprobe Gemini II system (Promega) and in situ grade ${ }^{35}$ S-UTP (Amersham). Radio- active probes were hydrolyzed at $60^{\circ} \mathrm{C}$ in $40 \mathrm{mM} \mathrm{NaHCO} / 60 \mathrm{mM}$ $\mathrm{NaCO}_{3}$ to a target length of $150 \mathrm{bp}$.

For in situ hybridization, cells were plated on glass chamber slides (Lab-Tek, Naperville, IL), allowed to settle for 3 minutes, then fixed with $2 \%$ paraformaldehyde (PFA) and $0.2 \%$ triton-X 100 at room temperature for 30 minutes. The fixative was aspirated off completely and $3 \times$ phosphate-buffered saline (PBS) was added for 2 minutes to stop the reaction. Following this, cells were rinsed with $1 \times$ PBS twice, 2 minutes each, and dehydrated with $50 \%$, $70 \%, 95 \%$, and twice with $100 \%$ ethanol for 5 minutes each. The slides were then allowed to dry completely at room temperature for 30-60 minutes, and stored at $-70^{\circ} \mathrm{C}$ until used. Cells fixed on chamber slides were rehydrated, then acetylated, followed by gradual dehydration in ethanol. Hybridization was performed overnight at $50^{\circ} \mathrm{C}$ in a humid chamber, and cells were overlaid with a hybridization solution containing $50 \%$ formamide, $1 \times$ hybridization buffer (10 mM Tris, $0.3 \mathrm{M} \mathrm{NaCl}, 1 \mathrm{mM}$ EDTA, $\mathrm{pH} 7.5), 1 \times$ Denhardt's solution, $100 \mu \mathrm{g} / \mu \mathrm{l}$ sheared salmon sperm DNA, 500 $\mu \mathrm{g} / \mu \mathrm{l}$ of tRNA, $10 \mathrm{mM}$ DTT (dithiothreitol), $10 \%$ dextran sulfate, and $10^{6} \mathrm{cpm}$ of probe $/ 100 \mu \mathrm{l}$. After posthybridization washes in 4 $\times$ SSC, cells were treated with RNase A and then washed sequentially with decreasing concentrations of SSC containing $1 \mathrm{mM}$ DTT, finally incubating in $0.1 \times \mathrm{SSC}$ with $1 \mathrm{mM}$ DTT at $60^{\circ} \mathrm{C}$ for 30 minutes. Following the high stringency incubation, slides were dehydrated quickly in ascending concentrations of ethanol, dried, and exposed to X-ray film for 1-3 days to determine efficiency of hybridization. Slides were then coated with NTB-2 emulsion from Kodak and stored in a dark desiccated container at $4^{\circ} \mathrm{C}$ for an appropriate time, determined by X-ray film results, usually 1 week to 1 month. Slides were developed using Kodak D-19 developer and rapid fixer, and were counterstained with hematoxylin/eosin.

\section{Results}

\section{Enzyme Treatment and Cell Attachment}

Because odontoblasts are surrounded by an intricate array of collagen fibrils [21, 22], collagenase IA was used as the principal enzyme in this protocol; elastase, DNAase I, hyaluronidase IS, and the nonspecific proteolytic enzymes trypsin I and protease I were employed to digest the proteins insensitive to collagenase. Among combinations of enzymes, $3 \mathrm{mg} / \mathrm{ml}$ collagenase IA and $0.25 \mathrm{mg} / \mathrm{ml}$ protease I yielded the largest quantity of well-isolated and relatively intact odontoblasts. Though adding trypsin I typically resulted in adequate isolation of these cells, many odontoblasts appeared to spread and most had a granular surface, suggesting damage to the membrane. Replacing protease I with elastase also produced many intact odontoblasts, but these cells had a tendency to remain in clusters and did not firmly adhere to the substrate. Likewise, $1 \mathrm{mg} / \mathrm{ml}$ protease I resulted in odontoblasts that attached to the substrate, yet a high-resistance seal was difficult to form in these cells. Adding DNAase or hyaluronidase IS to the standard mixture, substituting ECS with DME, or perfusion with $\mathrm{O}_{2}$ during incubation did not give rise to any significant improvement in isolating these cells. One objective in developing a new isolation procedure was to improve attachment of odontoblasts cells to either glass or plastic surfaces; without first immobilizing cells, application of patch-clamp methodologies is difficult to achieve. In general, odontoblast cells did not readily attach to either plastic or glass, and to promote adherence, surfaces were coated with Celltak, Sigmacote, fibronectin, collagen I, or poly-L-lysine. Of these treatments, only $0.01 \%$ poly-L-lysine effectively promoted odontoblast attachment without damage to the cell itself.

\section{Morphology and In Situ Hybridization}

A typical example of a well-isolated odontoblast is shown in 

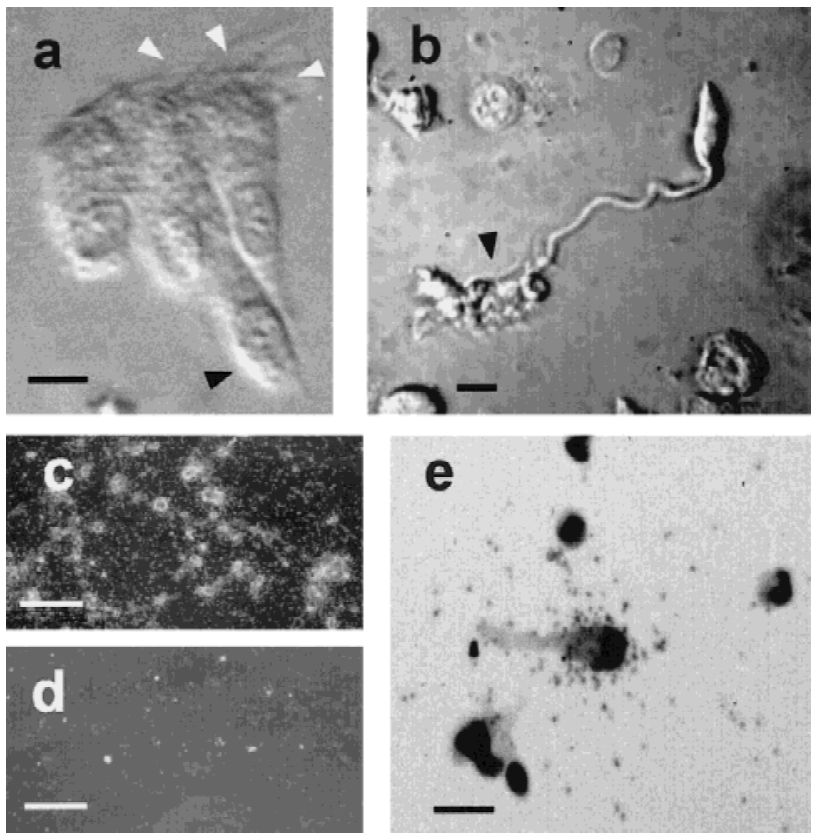

Fig. 1. Odontoblasts isolated using (a) a conventional technique and (b) as described in the present study. (a) Odontoblasts isolated from rat maxillary incisor using a surgical curette. Note the granular surface of the cells' membrane and truncated processes that extend from the distal end of each cell (white arrowheads). The nuclei can be seen at the base of each cell (black arrowhead). (b) A well isolated odontoblast shows an intact process that measured $\sim 80 \mu \mathrm{m}$; this cell had a smooth surface and the distal end of the process displayed fine branching (arrowhead). (c-e) Expression of DSP mRNA in isolated odontoblasts. (c) Low-power, dark-field photomicrograph of odontoblasts shows expression of DSP. (d) Sense control for expression of DSP. (e) Higher magnification of (c) shows expression of DSP in a single odontoblast. Scale barc-d: $100 \mu \mathrm{m} ; \mathrm{a}-\mathrm{b}$, e: $10 \mu \mathrm{m}$.

Figure 1b. Characteristic morphological features, including size and shape of the cell, length and diameter of the process, and polarization of the nucleus distinguished odontoblasts from all other cell types found in final suspensions, including erythrocytes, fibroblasts, endothelial cells, and dendritic cells. Further identification of these cells as odontoblasts was confirmed using in situ mRNA hybridization for expression of dentin sialoprotein (DSP) (Fig. $1 \mathrm{c}-\mathrm{e}$ ), as well as bone sialoprotein (BSP), osteocalcin (OCN), and collagen I (data not shown). Distribution of DSP mRNA in the total suspension of cells is shown in Figure $1 \mathrm{c}-\mathrm{d}$, and localization within a single odontoblast is illustrated in Figure 1e. Typically, DSP expression was limited to the odontoblast cell body, although in many cases, signal included the dentinal process; in the example shown in Figure 1e, a dense signal can be seen overlying the cell body.

\section{Electrophysiology and Microfluorometry}

Odontoblasts isolated with this method were suitable for the application of standard patch-clamp techniques routinely used in our laboratory [11]. Indeed, the success rate for formation of a high resistance seal was characteristic of connective tissue cells in general, and ranged from 40 to $80 \%$ in odontoblasts. An example of a typical recording is shown in Figure 2a, in this case, obtained 6 hours after isolation of the odontoblast; this patch contained a $139 \mathrm{pS}$ a.

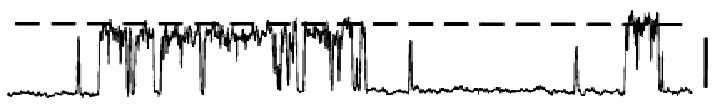

b.

C.
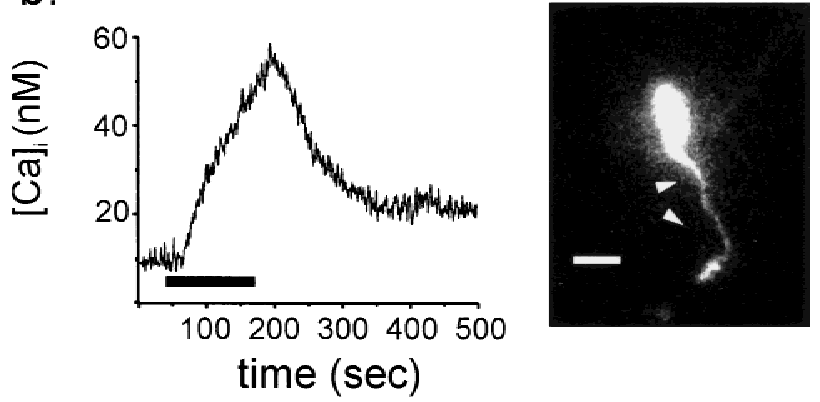

Fig. 2. Examples of (a) patch-clamp electrophysiology and (b,c) microfluorometry in odontoblasts. (a) Single-channel currents in an excised, outside-in patch containing a single $\mathrm{K}^{+}$-selective channel. Inward (positive) currents are shown as upward deflections, and the open state of the channel is indicated by the dashed line. The patch pipette had a tip resistance of $2.2 \mathrm{M} \Omega$ which increased to $20 \mathrm{G} \Omega$ after formation of the high-resistance seal. Horizontal scale: $20 \mathrm{~ms}$; vertical scale: $1 \mathrm{pA}$. (b) Effects of high potassium on intracellular calcium in a single odontoblast. In this experiment, ECS was replaced with ICS (solid bar) to depolarize the cells, resulting in calcium influx via voltage-gated channels. (c) Photomicrograph of an odontoblast that had been loaded for 30 minutes with fura-2. Scale bar: $20 \mu \mathrm{m}$.

$\mathrm{K}^{+}$-selective ion channel. In addition to electrophysiological studies, microfluorometric techniques were used to monitor internal calcium in these cells. The effect of membrane depolarization on $\left[\mathrm{Ca}^{2+}\right] \mathrm{i}$ is shown in Figure $2 \mathrm{~b}$. In this experiment, the cell was perfused with a potassium-rich solution, resulting in an increase in internal calcium, probably the result of activation of voltage-gated $\mathrm{Ca}^{2+}$ channels and influx of external $\mathrm{Ca}^{2+}$. A fluorescent image of a fura2-loaded single odontoblast is shown in Figure 2c, with its dentinal process clearly visible, extending from the apical aspect of the cell (arrowheads).

\section{Discussion}

This study describes a new method for isolating odontoblasts from incisors of adult rat using a combination of proteolytic enzymes followed by mechanical trituration. Odontoblasts isolated using this method typically had a columnar or cuboidal cell body, a uniform appearance to the cell's surface, and an intact process. Typically, these cells could not be maintained under conventional tissue culture conditions, yet could survive for up to 24 hours after isolation in ECS or DME medium when stored at $3-5^{\circ} \mathrm{C}$. In addition, though cells did not readily attach to either plastic or glass, coating the surface of the substrate with $0.01 \%$ poly-L-lysine predictably resulted in attachment of cells without damaging their membrane.

In addition to morphological criteria, cells were identified as odontoblasts using in situ mRNA hybridization for expression of both odontoblast-specific, i.e., DSP (Fig. 1 $\mathrm{c}-\mathrm{e})$, as well as nonspecific markers, including BSP, OCN, and collagen I. The selection of these markers for characterizing the odontoblast phenotype was based on previous 
immunocytochemical and in situ hybridization studies which demonstrated that sialic acid-rich glycoproteins, including BSP and DSP, as well as the glutamic acidcontaining protein $\mathrm{OCN}$, are expressed by odontoblasts at specific stages of tooth development [1, 23-25].

BSP is considered an excellent marker for mineralized tissues in general because of its relative specificity for these tissues, where it is found at high levels in bone and cementum, with lower levels noted in dentin [25]. Evidence to date supports a role for this molecule in the initiation of biomineralization [26-28] and in the promotion of cell adhesion [29]. DSP expression, on the other hand, is a characteristic feature of the odontoblast, and is not expressed by osteoblasts, cementoblasts, or fibroblasts. Recent data indicate that dentin phosphoprotein (DPP), also considered a dentinspecific protein, and DSP are expressed from a single cDNA transcript [30]. The exact function of these molecules is unknown, although suggested roles include as a modulator of hydroxyapatite formation and as a signaling molecule. Osteocalcin, also known as bone 'gla' protein, is restricted to mineralized tissues including bone, dentin, and cementum. Data suggest that OCN may play a role in regulating crystal growth and also in recruiting osteoclast progenitor cells to regions of bone resorption [31]. In addition, cells were also examined for expression of type I collagen, the major collagen associated with odontoblasts [23].

Application of single-channel patch clamp techniques to individual odontoblasts isolated using this new protocol has provided direct evidence for high-conductance potassiumand chloride-selective ion channels in the odontoblast membrane [11]. Among other functional properties, in nonexcitable cells like the odontoblast, these two classes of ion channel regulate membrane potential and cell volume [32, 33]. We have also used fura- 2 microfluorometry to monitor intracellular calcium levels in single odontoblasts, and show evidence for a voltage-gated calcium transient in these cells. In the odontoblast, a change in intracellular calcium may result from activation of voltage-sensitive and voltageinsensitive calcium channels $[4,6]$, a $\mathrm{Ca}^{2+}-\mathrm{Na}^{+}$antiporter [34], and/or an ATP-dependent calcium pump [35], and represents one of the earliest signals in a cascade of events leading to the expression and release of extracellular matrix proteins prior to mineralization [36]. Further, during mineralization itself, the transport of calcium from the serum to the mineralizing front is critical [5], and recent studies indicate an important role for a number of calcium-conducting pathways in the odontoblast during this stage of the process $[36,37]$. Indeed, the fact that odontoblast calcium (and other) channels may be important during dentinogenesis is consistent with the important role that osteoblast ion channels play in mineral formation in bone. The osteoblast membrane contains a diverse population of such channels [38, 39 ], and the activity of these channels is linked to a variety of events related to mineralization [40, 41].

In summary, this study describes a new isolation procedure for odontoblasts that results in mature, intact cells that represents a distinct advantage over previous methods in that it preserves the dentinal process, perhaps the most unique anatomical feature of these cells. Moreover, cells isolated with this technique were suitable for the application of electrophysiological, molecular, and microfluorometric techniques. Although exact mechanisms have yet to be defined, odontoblasts are known to play a critical role during the formation of mineralized tissue in developing and mature teeth and may also contribute to sensory transduction in dental pulp. This new method to isolate odontoblasts pro- vides an interesting and valuable in vitro preparation for continued study of these two important processes.

Acknowledgments. This research was supported by grant DE11651 from NIH/NIDCR to RMD.

\section{References}

1. Butler WT (1998) Dentin matrix proteins. Eur J Oral Sci 106 (suppl 1):204-210

2. Matthews B, Andrew D, Amess TR, Ikeda H, Vongsavan N (1996) The functional properties of intradental nerves. In: Shimono M, Maeda T, Suda H, Takahashi K (eds) Dentin/pulp complex. Quintessence Publishing Co, Tokyo, pp 146-153

3. Smutzer G, Zimmerman JE, Han LY, Ruscheinsky DD, Arnold SE, Yu X, Kratskin I (1997) Inositol 1,4,5-trisphosphate receptor expression in odontoblast cells. Biochim Biophys Acta 1358:221-228

4. Lundgren T, Linde A (1997) Voltage-gated calcium channels and nonvoltage-gated calcium uptake pathways in the rat incisor odontoblast plasma membrane. Calcif Tissue Int 60:7985

5. Linde A (1995) Dentin mineralization and the role of odontoblasts in calcium transport. Connect Tissue Res 33:163-170

6. Seux D, Joffre A, Fosset M, Magloire H (1994) Immunohistochemical localization of L-type calcium channels in the developing first molar of the rat during odontoblast differentiation. Arch Oral Biol 39:167-170

7. Larmas M, Kortelainen S, Backman T, Hietala E, Pajari U (1992) Odontoblast-mediated regulation of the progression of dentinal caries. Proc Finn Dent Soc 88 (supp 1):313-320

8. Magloire H, Bouvier M, Joffre A (1992) Odontoblast response under carious lesions. Proc Finn Dent Soc 88 (supp 1):257274

9. Turner D (1992) Immediate physiological response of odontoblasts. Proc Finn Dent Soc 88 (supp 1):55-63

10. Salzberg BM (1985) New approaches to the neurophysiology of the dental pulp. J Dent Res 64:597-601

11. Guo L, Davidson RM (1998) Potassium and chloride channels in freshly isolated rat odontoblasts. J Dent Res 77:341-350

12. Hamill OP, Marty A, Neher E, Sakmann B, Sigworth F (1981) Improved patch-clamp techniques for high resolution current recording from cells and cell-free membrane patches. Pflugers Arch 391:85-100

13. Linde A (1972) A method for the biochemical study of enzymes in the rat odontoblast layer during dentinogenesis. Arch Oral Biol 17:1209-1212

14. Grynkiewicz G, Poenie M, Tsien RY (1985) A new generation of $\mathrm{Ca}^{2+}$ indicators with greatly improved fluorescence properties. J Biol Chem 260:3440-3450

15. Zeller R, Rogers M (1994) In situ hybridization and immunohistochemistry. In: Ausubel FM, Brent R, Kingston RE, Moore DD, Seidman JG, Smith JA, Struhl K (eds) Current protocols in molecular biology. John Wiley \& Sons, New York, pp 14.3.1-14.4.3

16. Ritchie HH, Berry JE, Somerman MJ, Hanks CT, Bronckers AL, Hotton D, Papagerakis P, Berdal A, Butler WT (1997) Dentin sialoprotein (DSP) transcripts: developmentally sustained expression in odontoblasts and transient expression in pre-ameloblasts. Euro J Oral Sci 105:405-413

17. Ritchie HH, Hou H, Veis A, Butler WT (1994) Cloning and sequence determination of rat dentin sialoprotein, a novel dentin protein. J Biol Chem 269:3698-3702

18. Young MF, Ibaraki K, Kerr JM, Lyu MS, Kozak CA (1994) Murine bone sialoprotein (BSP): cDNA cloning, mRNA expression, and genetic mapping. Mamm Genome 5:108-112

19. Celeste AJ, Rosen V, Buecker JL, Kriz R, Wang EA, Wozney JM (1986) Isolation of the human gene for bone gla protein utilizing mouse and rat cDNA clones. EMBO J 5:1885-1890 
20. Fisher LW, Whitson SW, Avioli LV, Termine JD (1983) Matrix sialoprotein of developing bone. J Biol Chem 258:1272312727

21. Higashi T, Okamoto H (1996) Electron microscopic study on interodontoblastic collagen fibrils in amputated canine dental pulp. J Endod 22:116-119

22. Bishop MA, Malhotra M, Yoshida S (1991) Interodontoblastic collagen (von Korff fibers) and circumpulpal dentin formation: an ultrathin serial section study in the cat. Am J Anat 191:67-73

23. Bronckers AL, D'Souza RN, Butler WT, Lyaruu DM, van Dijk S, Gay S, Woltgens JHM (1993) Dentin sialoprotein: biosynthesis and developmental appearance in rat tooth germs in comparison with amelogenins, osteocalcin and collagen type-I. Cell Tissue Res 272:237-247

24. Chen J, McCulloch CAG, Sodek J (1993) Bone sialoprotein in developing porcine dental tissues: cellular expression and comparison of tissue localization with osteopontin and osteonectin. Arch Oral Biol 38:241-249

25. MacNeil RL, Sheng N, Strayhorn CL, Fisher LW, Somerman MJ (1994) Bone sialoprotein is localized to the root surface during cementogenesis. J Bone Miner Res 9:1597-1606

26. Hunter GK, Goldberg HA (1993) Nucleation of hydroxyapatite by bone sialoprotein. Biochem 90:8562-8565

27. McKee MD, Nanci A (1995) Osteopontin and the bone remodeling sequence. Colloidal-gold immunocytochemistry of an interfacial extracellular matrix protein. Ann NY Acad Sci 760:177-189

28. McKee MD, Nanci A (1995) Postembedding colloidal-gold immunocytochemistry of noncollagenous extracellular matrix proteins in mineralized tissues. Microsc Res Tech 31:44-62

29. Somerman MJ, Fisher LW, Foster RA, Sauk JJ (1988) Human bone sialoprotein I and II enhance fibroblast attachment in vitro. Calcif Tissue Int 43:50-53

30. MacDougall M, Simmons D, Luan X, Nydegger J, Feng J, Gu TT (1997) Dentin phosphoprotein and dentin sialoprotein are cleavage products expressed from a single transcript coded by a gene on human chromosome 4. Dentin phosphoprotein DNA sequence determination. J Biol Chem 272:835-842

31. Luo G, Ducy P, McKee MD, Pinero GJ, Loyer E, Behringer RR, Karsenty G (1997) Spontaneous calcification of arteries and cartilage in mice lacking matrix GLA protein. Nature 386:78-81

32. Hille B (1992) Ionic channels of excitable membranes. Sinauer, Sunderland, MA pp 115-139

33. Jentsch TJ, Gunther W (1997) Chloride channels: an emerging molecular picture. Bioessays 19:117-126

34. Lundgren $\mathrm{T}$, Linde A (1988) $\mathrm{Na}^{+} / \mathrm{Ca}^{+}$antiports in membranes of rat incisor odontoblasts. J Oral Pathology 17:560-563

35. Granstrom G, Linde A (1981) ATP-dependent uptake of $\mathrm{Ca}^{2+}$ by a microsomal fraction from rat incisor. Calcif Tissue Int $33: 125-128$

36. Linde A, Lundgren T (1995) From serum to the mineral phase: the role of the odontoblast in calcium transport and mineral formation. Int J Dev Biol 39:213-222

37. Lundgren T, Linde A (1992) Calcium ion transport kinetics during dentinogenesis: effects of disrupting odontoblast cellular transport systems. Bone Miner 19:31-44

38. Duncan RL, Akanbi KA, Farach-Carson MC (1998) Calcium signals and calcium channels in osteoblastic cells. Semin Nephrol 18:178-190

39. Ypey DL, Weidema AF, Hoeld KM, Van der Laarse A, Ravesloot JH, Van der Plas A, Nijweide PJ (1992) Voltage, calcium, and stretch activated ionic channels and intracellular calcium in bone cells. J Bone Miner Res 7:S377-S387

40. Li W, Duncan RL, Karin NJ, Farach-Carson MC (1997) $1,25(\mathrm{OH}) 2 \mathrm{D} 3$ enhances PTH-induced $\mathrm{Ca}^{2+}$ transients in preosteoblasts by activating L-Type $\mathrm{Ca}^{2+}$ channels. Am J Physiol 273:E599-E605

41. Kawase T, Burns DM (1998) Calcitonin gene-related peptide stimulates potassium efflux through adenosine triphosphatesensitive potassium channels and produces membrane hyperpolarization in osteoblastic UMR106 cells. Endocrinology 139:3492-3502 